RESEARCH PAPER ON

\title{
PUBLIC POLICY AND MANAGERIAL IMPLICATIONS OF GREEN MARKETING - NEED OF THE HOUR
}

\author{
${ }^{1}$ Dr. M.Muninarayanappa \\ ${ }^{2}$ Dr. M.Nirmama
}

\begin{abstract}
This paper examines issues in understanding the relationship between the marketing discipline, the public policy process and the natural environment. Many terms describe this relationship, although the notion of marketing is more expansive, this paper employs the term green marketing to refer to the public policy and managerial implications to promote products by employing environmental claims either about their attributes or about the systems, policies and processes of the firms that manufacture or sell them. Along with manipulating the traditional marketing mix, it requires an understanding of public policy processes. Green marketing also ties closely with issues of industrial ecology and environmental sustainability such as extended producers' liability, life-cycle analysis, material use and resource flows, and eco-efficiency. Thus, the subject of green marketing is vast, having important implications for public policy.
\end{abstract}

\section{Introduction :}

Green marketing is the process of selling products and/or services based on their environmental benefits. Such a product or service may be environmental friendly in itself or produced and/or packaged in an environmental friendly way. The obvious assumption of green marketing is that potential consumers will view a product or service's "greenness" as a benefit and base their buying decision accordingly. The notso-obvious assumption of green marketing is that consumers will be willing to pay more for green products than they would for a less-green comparable alternative produce an assumption that, in my opinion, has not been proven conclusively. While green marketing is growing greatly as increasing number of consumers are willing to back their environmental consciousnesses with their money, it can be dangerous. The public tends to be skeptical of green claims to begin with and companies can seriously damage their brands and their sales if a green claim is discovered to be false or contradicted by a company's other products or practices. Presenting a product or service as green when it's not is called green washing.

So in this scenario of global concern, corporate houses has taken green-marketing as a part of their strategy to promote products by employing environmental claims either about their attributes or about the systems, policies and processes of the firms that manufacture or sell them. Clearly green marketing is part and parcel of overall corporate strategy; along with manipulating the traditional marketing mix (product, price, promotion and place), it require an understanding of public policy process. So we can say green marketing covers a broad range of activities. Different writers have given different definition about green marketing which tried to cover all major components of green marketing.

1 Associate Professor, Department of Commerce, Bangalore University

2 Assistant Professor, CBSMS Bangalore University 
According to Polonsky (1994)- green or environmental marketing consists of all activities, designed to generate and facilitate any exchange intended to satisfy human needs and wants, such that the satisfaction of these needs and wants occur with minimum detrimental impact on the natural environment.

\section{Firms can 'green' themselves in three ways:}

- Value-addition processes (firm level): Greening the value-addition processes could entail redesigning them, eliminating some of them, modifying technology and/or inducting new technology - all with the objective of reducing the environmental impact aggregated for all stages. A steel firm may install a state-of-the-art furnace (new technology), thereby using less energy to produce steel. Firms could adopt management systems that create conditions for reducing the environmental impact of value-addition processes. A good example is the Responsible Care program of the chemical industry, which establishes systems to promote environmental, health and safety objectives.

- Management systems (firm level) : However, management systems' efficacy for greening value-addition processes is difficult to quantify if they are not accompanied by performance measures. Thus, by having measurable performance indicators, firms can make verifiable claims about the environmental impact of their management systems. Conceivably, consumers may reward such firms, if they can easily access and interpret such information.

- Products (product level): The third greening strategy pertains to products. Building on Charter (1992), this could take place in the following ways:

(i) repair - extend the life of a product by repairing its parts;

(ii) recondition - extend the life of a product by significantly overhauling it; (iii) remanufacture - the new product is based on old ones;

(iv) reuse - design a product so that it can be used multiple times;

(v) recycle - products can be reprocessed and converted into raw material to be used in another or the same product - and

(vi) reduce- even though the product uses less raw material or generates less disposable waste, it delivers benefits comparable to its former version or to competing products.

In addition, greening products could include 'designing for the environment' and devising new institutions to reduce environmental impact of product use by developing systems to replace dominant pattern of private ownership and use (as in cars) by a mix of collective and private use (through leasing and renting).

Go green by : Here are just ten easy-to-implement ideas for running a green business from the Department of Foreign Affairs and International Trade's Greening Operations guides that you can put into practice right now to make your business a more environmental friendly place.

Whether you run a home-based business or a brickand-mortar retail business an off-site enterprise, there are simple, easy things you can do to go green. And operating a green business is not only good for the environment but good for your business's bottom line because conserving resources and cutting down on waste saves money.

1. Turning off equipment when it's not being used. This can reduce the energy used by 25 percent; turning off the computers at the end of the day can save an additional 50 percent.

2. Encouraging communications by email, and reading email messages onscreen to determine whether it's necessary to print them. If it's not, don't!

3. Reducing fax-related paper waste by using a fax-modem and by using a fax cover sheet only when necessary. Fax-modems 
allow documents to be sent directly from a computer, without requiring a printed hard copy.

4. Producing double-sided documents whenever possible.

5. Not leaving taps dripping; always close them tightly after use. (One drop wasted per second wastes 10,000 litres per year.)

6. Installing displacement toilet dams in toilet reservoirs. Placing one or two plastic containers filled with stones (not bricks) in the toilet's reservoir will displace about 4 litres of water per flush - a huge reduction of water use over the course of a year.

7. Finding a supply of paper with maximum available recycled content.

8. Choosing suppliers who take back packaging for reuse.

9. Instigating an ongoing search for "greener" products and services in the local community. The further your supplies or service providers have to travel, the more energy will be used to get them to you.

10. Before deciding whether you need to purchase new office furniture, see if your existing office furniture can be refurbished. It's less expensive than buying new and better for the environment.

\section{PUBLIC POLICY}

\section{Green responsibility}

There is an increasing need for businesses to emphasize on green marketing concerns in their mission statements. Green efforts must also prove to be economically viable for companies to engage in green marketing activities. Green Marketing remains the responsibility of the main stakeholders - consumers, the business and the government. The results show that a serious effort to green up a company's image can yield long-term and even global benefits.

\section{Market and Non-Market contexts :}

Firms may choose to green their systems, policies and products due to economic and non economic pressures from their consumers, business partners, regulators, citizen groups and other stakeholders. As David Baron (1995) has argued, market and nonmarket environments impact each other. Thus, firms need to adopt an integrated approach to their market (in the context of household consumers in the discussion below) and nonmarket strategies. For example, in adopting green marketing policies, firms may encounter many challenges such as a disconnect between consumers' attitudes and actual behaviors, and their unwillingness to pay premiums for green products. This may be partially rooted in consumers' skepticism of environmental claims. Thus, regulatory and policy issues on environmental claims (such as labeling or advertising) that arise in the nonmarket arenas may have bearing on firms' market strategies. Key market and nonmarket challenges are examined below.

\section{Consumers: attitudes versus behaviors}

Increasing attention is being paid to packaging, a component of product in the marketing mix. It is being recognized that packaging is important not only from a functional viewpoint, but also in terms of marketing to the customer. One of the constraints on packaging is environmental issues. These are becoming increasingly important internationally, from both a legislative and consumer perspective. In this study the perceptions of the members of the packaging value chain as regards the functional, marketing and environmental issues surrounding packaging have been examined. It is found that functional aspects appear to be the most important, followed by marketing aspects.

Some scholars believe that consumers are willing to pay premiums for green products because consumers often prioritize green attributes over traditional product attributes such as price and quality: $50 \%$ of Americans claim to look for environmental labels and to switch brands based on environment-friendliness. However, the caveat is that such claims and attitudes may not always translate into actual behaviors. One reason could be the social pressures to be 'green'. Consequently, at withstanding the claims about the concern for the natural environment, mass consumer markets for green products in most categories have yet to 
develop. Some scholars claim that green policies/ products are profitable: green policies can reduce costs; green firms can shape future regulations and reap first-mover advantages (Porter and van der Linde, 1995; for a critique, see Rugman and Verbeke, 2000). However, this does not seem to be the norm within and across most industries. Many believe that green policies are expensive, especially after the initial gains - the 'low hanging fruit' in reducing end-of-thepipe pollution have been harvested (Walley and Whitehead, 1994). As a result, firms often need to charge premium prices for green products. Of course, if green products were cheaper than other products, their premium pricing would be less of an issue for consumers. The above discussion raises two issues regarding consumers' benefit-cost calculus: first, whether consumers regard greenness of products/ firms as 'hygiene' or 'motivating' factors, and second, to what extent green products create social benefits but impose private costs. Extending Maslow's (1943) theory, Herzberg (1966) developed a theory of work motivation that focused on two work-related factors: those that motivated employees (motivators) and those that prevented dissatisfaction among them (hygiene). As discussed in Prakash (2000), a key challenge for marketers is to understand whether consumers view firm/product greening as motivating factors (their presence induces consumers to purchase a given product; preference for a product is an increasing function of the greening level) or hygiene factors (their absence may bother consumers but, after a low threshold of greening, the preference for a product is not an increasing function of the greening level). If consumers favor firms with green policies (for example, the one with ISO 14001 certification is preferred) or green products (for example, the one with a higher percentage of recycled inputs is favored), green policies/products are motivating factors. Managers, therefore, have economic justification to ensure that their firms/products are greener than their competitors'. However, if consumers do not care much about who is greener, but they do penalize firms that violate environmental laws or remit high levels of toxins, greenness is a hygiene variable $-33 \%$ of adults claimed to have avoided buying products, at least occasionally, from companies with poor environmental records (Ottman, 1996). If so, then the managerial task then is to obey environmental laws, to stay out of trouble with the regulators and to avoid bad press by undertaking minimal beyond-compliance initiatives.

\section{Green Communication Strategy}

In many instances, the environmentally damaging aspect of a product as technical in nature (e.g mercury on batteries or phosphate in washing powders), consumers need to be educated on the hazards of using such products and the benefits of using their green equivalents. Thus communication is another key factor to the marketing of the green products. The present suggests that opportunities exist for advertisers to implement successful green appeal campaigns.

\section{Environmental Consumerism}

Participants with specific beliefs about the environmental impact of the purchase and use of consumer products are very likely to hold proenvironment attitudes. For instance, people who attached importance to the purchase of products made with recyclable materials or packaged in reusable containers were more likely to care about the quality of the environment and the wise stewardship of natural resources. Women and men were equally likely, however, to attempt to conserve natural resources, to take part in political or organizational activities for environmental reasons, and to consider safety to the environment when buying a product.

\section{Eco-strategic change management concept}

Just like any integrated marketing communication approach, green marketing must involve extensive coordination across functional areas to be effective. The level of greening — strategic, quasi-strategic, or tactical-dictates exactly what activities should be undertaken. Strategic greening in one area may or may not be leveraged effectively in others. A firm could make substantial changes in production processes but opt not to leverage them by positioning itself as an environmental leader. So although strategic greening is not necessarily strategically integrated into all marketing activities, it is nevertheless strategic in the product area. 
To realize these strategic benefits will require an innovative firm with the will to question the very basis of what and how it operates. Innovative companies choosing to adopt a strategic environmental marketing focus need to continually reevaluate and improve their overall performance. This is necessary because knowledge and acceptable environmental practices are continually changing. Such a focus requires extensive commitment of resources and topmanagement support, which may be difficult to maintain, especially in times of broader turbulence in the business environment.

\section{Corporate environmentalism and adopting an enviropreneurial approach to marketing}

Corporate environmentalism is an imperative for business, and companies that go green should have a first-mover advantage over those that do not although it is a continuous rather than a onetime process of renewal that improves a firm's environmental and financial performance. To this end, companies may wish to consider adopting the enviropreneurial approach to marketing, "blending environmental concerns with marketing strategy in search of innovations and opportunities". By seeing these new situations as opportunities, firms can strive to maximize them and provide improved competitive advantage at the expense of competitors that either overlook such opportunities or view them as threats.

\section{MANAGERIAL IMPLICATIONS}

Green marketing subsumes greening products as well as greening firms. Though normative concerns impact consumers' and firms' decision making, economic aspects of green marketing should not be neglected. Managers need to identify what ought to be greened: systems, processes or products? Consumer apathy to green products is due to many factors, including inadequate information about levels of greenness, lack of credibility of firms' claims and the tendency to free ride. It also seems that green products that offer direct excludable benefits to consumers (such as pharmaceuticals with minimum side effect and nutritious and natural foods) would have higher acceptability. Consumer apathy may also be attributed to the belief that individual actions alone cannot impact the macro picture, and collective endeavors are impeded by free riding. To tackle these market-related problems, perhaps initiatives in the nonmarket environment may bear fruit. To curb free riding and to reassure consumers that their actions will have macro impact, some green marketers favor policies/regulations that lead to collective sacrifices. This leads to another set of challenges, because environmental issues are often highly contested in terms of their etiologies and solutions. Many such disputes are attributable to ideological and economic factors. To some, collective sacrifices signify intrusive big government and side-stepping individual responsibility.

Economic considerations are even more complex. Actors may favor the status quo if the proposed collective sacrifice imposes costs on them. If the benefits are diffused, policy supporters could have difficulties in mobilizing winning coalitions. On the other hand, with concentrated benefits and diffused costs, mobilizing winning coalitions to support collective sacrifices is easier. When both benefits and costs are concentrated or diffused, the outcomes are difficult to predict. As this discussion suggests, the tasks of green marketers who favor collective sacrifices as vehicles for achieving their objectives are complicated by the politics of the nonmarket environment. Information provision about greenness is a key component of green marketing. Clearly, firms should not advertise products' environmental benefits unless such claims can be credibly substantiated. Negative press reports on false or exaggerated claims often lead to decreased sales (Polonsky, 1995). Firms can also form strategic alliances, including product endorsements and corporate sponsorships from environmental groups that provide credibility to their environmental claims. Further, firms willing to provide clear, comprehensive and credible information must ensure that consumers have low-cost access to it. Again, governmental policies and stakeholder initiatives can be important in reducing consumers' search, information or transaction costs. Regulators can publish it (for example in the Federal Register), disseminate it to the media by press releases and post it on the Internet (see the citations on FTC and EPA websites). Stakeholders can also use the media as well as use 
their organization-specific vehicles such as newsletters. Finally, if managers believe that consumers view greenness as a motivating variable, they should invest in conveying information through advertising, direct mailing, brand labels, in-store displays and pamphlets. Our understanding of green marketing is still in its infancy, perhaps due to the multidisciplinary nature of the enterprise. Marketing scholars focus on a host of business strategy and public policy issues, including eco-labels and market segmentation, and the role of structural factors and economic incentives in influencing consumer behavior. For environmental economists, green marketing signifies a broader trend in the evolution of environmental policies that focus on information disclosure. Institutional theory, stakeholder theory and the corporate social performance perspective view green marketing as a subset of corporate policies designed to gain external legitimacy. These have developed in response to the expectations of a broad spectrum of stakeholders, both internal and external. Political economists focus on collective action dilemmas inherent in green marketing at the consumer and producer levels. This paper has identified key ideas in relation to promoting green products that may be most relevant to both scholars and practitioners of green marketing.

\section{CONCLUSION}

The policy decisions above provide new insights into the future move that the main stakeholders, businesses, consumers and the government, must take for a greener country. However, the greening phenomenon is not static and it is highly recommended that the green movement be continuously studied and necessary strategies and tactics be adopted to cater for the intricacies of the consumers and environment.

\section{Reference :}

1) Aseem Prakash Bus. Strat. Env. 11, 285-297 (2002) Published online in Wiley InterScience. Prof. Moloy Ghoshal, Green marketing - A changing concept in changing time. "IMR-MgtSpeak., Vol 2, No-1,Jan-June 2008" issue.

2) Vogel D. 1996. Kindred Strangers: the Uneasy Relationshipbetween Politics and Business in America. Princeton University Press: Princeton, NJ.

3) Walley N, Whitehead B. 1994. It's not easy being green. Harvard Business Review May-June: 4651.

4) Weiner JL. 1993. What makes people sacrifice their freedom for the good of their community? Journal of Public Policy and Marketing 12: 244260.

5) Weiner JL, Doescher. 1991. A framework for promoting cooperation. Journal of Marketing 55: 387.

6) Wilson JQ. 1980. The Politics of Regulation. Basic Books:New York. 